\title{
RESISTANCE OF SEVERAL RICE VARIETIES AGAINST THE BACTERIAL PANICLE BLIGHT DISEASE (Burkholderia glumae)
}

\author{
Nurni Wahidah, Irda Safni, Hasanuddin, \& Lisnawita \\ Agrotechnology Study Program, Faculty of Agriculture, University of Sumatera Utara, Indonesia \\ Jl. Dr. A. Sofian No.3 Padang Bulan Kota Medan Sumatera Utara 20155 \\ E-mail: irda@usu.ac.id
}

\begin{abstract}
Resistance of several rice varieties against the bacterial panicle blight disease (Burkholderia glumae). Burkholderia glumae is included as A2 quarantine plant pest organism, which is found in some restricted area in Indonesia. B. glumae is a seedborne pathogen that causes panicle blight, seedling rot, grain rotand leaf sheath browning on rice plants. This research was objected to determine the resistance of five rice varieties against bacterial panicle blight pathogen. The experiment was carried out at the screen house of Faculty of Agriculture, University of Sumatera Utara, Medan from May to September 2018. This experiment was designed using Factorial Completely Randomized Design (CRD) with 2 factors; Factor 1: B1 (sterile water as negative control), B2 (B. glumae isolate CH BJ), B3 (B. glumae isolate IR 64), B4 (B. glumae isolate IC PRC), B5 (B. glumae isolate DSMZ $9512^{\mathrm{T}}$ as positive control). Factor 2: V1 (Cisokan variety), V2 (Inpari 4 variety), V3 (Situbagendit variety), V4 (Inpari 32 variety) and V5 (Cidenu variety). The results showed that all five rice varieties were highly susceptible to bacterial panicle blight pathogen. Inpari 32 variety had the highest number of seeds and weight of 100 seeds and had the lowest percentage of empty seeds. IR 64 variety had the lowest number of seeds and the weight of 100 seeds and had the highest percentage of empty seeds.
\end{abstract}

Key words: A2 quarantine plant pest organism, grain rot, seedborne pathogen, seedling rot

\section{INTRODUCTION}

Panicle blight caused by Burkholderia glumae bacteria was first reported in 1956 in the Kyushu area, Japan, and has since become one of the important diseases in the world (Xie et al., 2003; Kumar et al., 2017). This disease can cause yield loss of up to $75 \%$ in severely infected plants (Trung et al., 1993). In Indonesia, this disease has been appreared since 1987, but after that it had not been reported back to the existence of severe damage due to this disease until it began to be reported back in 2015 in several regions in Indonesia (Joko, 2017). Based on the regulation of the Minister of Agriculture of the Republic of Indonesia number 31/PERMENTAN/KR/010/7/2018 tahun 2018, B. glumae is included as A2 quarantine plant pest organism, which has been found in West Java, Central Java and East Java (Wiyono et al., 2017). South Sulawesi (Baharuddin et al., 2017), and recently it has been detected in North Sumatra (Hasibuan et al., 2017). Bacteria $B$. glumae is a seed-borne pathogen, therefore it is potential to spread to whole parts of Indonesia through seed trade (Suryani, 2017).

Symptoms of panicle blight can be seen in the panicle which will change color, the skin of the rice husk will be brownish in color or even rot and the grains become hollow, while the seeds experience blight or rot (Suryani, 2017; Wiyono et al., 2017).

In addition, this disease of panicle rice bacteria can inhibit seed germination, cause panicle base rot, sterile flowers, emptiness in grain and discoloration of grain (Nandakumar et al., 2009).

The use of resistant varieties is one of the effective ways to control, breeders also continue to work and assemble these resistant genes into rice varieties for the future (Wamishe et al., 2015). Moderate resistant varieties that can be used to fight panicle blight disease are Jupiter varieties (Kumar et al., 2017). Ciherang, Cibogo, Mekongga, Inpari 30, and IR64 varieties have been identified to be very susceptible to panicle blight disease bacteria (Weny, 2018; Weny et al., 2019). The use of resistant varieties can be the best alternative, but their availability is currently very limited and lacks the characteristics desired for commercialization (Zhou-qi et al., 2016). This study was aimed to evaluate the resistance of five rice varieties to $B$. glumae and examine the effect of interactions between rice varieties and $B$. glumae bacterial isolates, which cause bacterial panicle blight, on the resistance of rice varieties to these pathogens. 


\section{MATERIALS AND METHODS}

Research Site. The experiment was carried out at the Screen house, Faculty of Agriculture, University of Sumatera Utara from May to September 2018.

Experimental Design. This research used completely randomized design (CRD) with two factor. The first factor was isolates of B.glumae bacteria: B1 (sterile aquadest as negative control), B2 (CH BJ isolate), B3 (IR 64 isolate), B4 (IC PRC isolate), B5 (DSMZ 9512 isolate as positive control). The second factor was rice varieties: V1 (Cisokan variety), V2 (Inpari 4 variety), V3 (Situbagendit variety), V4 (Inpari 32 variety) dan V5 (Cidenu variety). Data was analyzed by analysis of variance (ANOVA) and further test Tukey HSD (honestly significance difference) with accuracy of 5\%, using SPSS programme. This experiment used 1 bucket per experimental unit, thus there were a total of 75 experimental units.

Bacterial Cultivation. Three isolates of B.glumae bacteria were taken from collection of Laboratory of Plant Disease, Faculty of Agriculture USU (CH BJ, IR 64, IC PRC isolates), including one type strain of $B$. glumae DSM $9512^{\mathrm{T}}$ which came from DSMZ Culture Collection Germany, cultivated by streaking technique and incubated at $30^{\circ} \mathrm{C}$ for 24 hours using King's B media (Nandakumar et al., 2009).

Preparation of Planting Materials. Five rice seed varieties obtained from Lubuk Pakam Seed Center, North Sumatra, namely Cisokan, Inpari 4, Situbagendit, Inpari 32, and Cidenu varieties, were prepared $500 \mathrm{~g}$ each. Each sample of seeds was put into a container and labeled, and then the samples were brought to the greenhouse for sowing.

Planting media in the form of non-sterilized soil paddy fields was placed into a plastic bucket until it meets $2 / 3$ part and was inundated with water. Seeding was done with sterile top soil media in a 7-days-old sprout to rice bath before being transplanted.

Planting in the Screen House. Buckets that have been filled with planting media, were arranged in a screen house with a distance between buckets was 30 $\mathrm{cm}$, then were planted with 2 seven-days old seedlings. Basic fertilization was carried out with recommended dosages, namely N, P and K fertilizers (625 mg urea/ bucket, $250 \mathrm{mg} \mathrm{SP-36/bucket,} \mathrm{and} 187.5 \mathrm{mg} \mathrm{KCl} /$ bucket respectively). Urea fertilizer was applied in several stages: at the age of 7 days after planting (DAP), $40 \%$ dose; at the age of 30 DAP, $30 \%$ dose, and at the age of 45 DAP, 30\% dose, while SP-36 fertilizer and $\mathrm{KCl}$ were applied at the age of 7 DAP.

Bacterial Inoculation. Bacterial inoculation was carried out at the time when rice enter the booting phase by injecting $0.5 \mathrm{~mL}$ of bacterial suspension with a concentration of $10^{8} \mathrm{CFU} / \mathrm{mL}$ on the leaf sheath using a $1 \mathrm{~mL}$ syringe (BD ${ }^{\text {TM }} 23 \mathrm{G} 1$ needles) (Nandakumar $e t$ al., 2009). Sterile aquadest was used as negative control.

\section{Observation Variables}

Disease Incidence. Observation of the disease symptoms was carried out every day after inoculation (DAI), the disease incidence was calculated when the disease symptoms appeared visually. Disease incidence was calculated using formulae as the following:

$$
\mathrm{DI}=\frac{\mathrm{a}}{\mathrm{b}} \times 100 \%
$$

$\mathrm{DI}=$ incidence of panicle blight disease

$\mathrm{a}=$ the number of infected plants by panicle blight disease

$\mathrm{b}=$ the number of observed plants

Disease Severity. Disease severity was calculated using formulae of Agrios (2005):

$$
\mathrm{DS}=\frac{\sum(\mathrm{n} \times \mathrm{v})}{\mathrm{N} \times \mathrm{Z}} \times 100 \%
$$

$\mathrm{DS}=$ disease severity

$\mathrm{N}=$ the number of plants per scoring

$\mathrm{v}=$ the value of disease scoring each individual plant

$\mathrm{Z}=$ the highest damage score

$\mathrm{n}=$ the number of observed plants

The scale showing the level of disease severity of panicle blight disease according to Devescovi et al. (2007) with modification is as the following:

Scale 0 : healthy panicle

Scale 1 : $0-20 \%$ of panicle change color

Scale $2: 20-40 \%$ of panicle change color

Scale $3: 40-60 \%$ of panicle change color

Scale $4: 60-80 \%$ of panicle change color

Scale $5: 80-100 \%$ of panicle change color

Number of Grains. The number of grains each plant were calculated after the rice grains were released from each panicle stalk during harvest time. 
Percentage of Empty Grains. Empty grains were separated from filled grains, then the empty grain presentation was calculated using this following formulae:

Percentage of empty grains $=\frac{\text { no. of empty grains }}{\text { no. of all grains }} \times 100 \%$

Weight of 100 Grains. Weight of filled grains was calculated the 100 grains each plants, then was weighed using analytical scale.

Plant Resistance. The criteria of rice resistance to panicle blight disease caused by $B$. glumae according to method of Groth et al. (1991), i.e. percentage of disease incidence caused by $B$. glumae is as the following (Table 1).

\section{RESULTS AND DISCUSSION}

Disease Incidence. Disease symptoms were observed every day after inoculation (DAI), the disease incidence was calculated when the symptoms of the disease were seen. The disease incidence reached $100 \%$ in all rice varieties and treatments of isolates at $13 \mathrm{DAI}$, including rice varieties inoculated with sterile aquadest (control) (Table 2.). All tested isolates could cause disease symptoms in all varieties. There were some differences of incubation periods, which several isolates on particular variety caused symptoms earlier, i.e. 8 DAI after symptom appeared, $10 \mathrm{DAI}$ and $11 \mathrm{DAI}$; although all plants showed symptoms at 13 DAI. From analysis data, there was no effect of interaction between rice varieties and tested isolates to the disease incidence.

The inoculated B. glumae bacteria entered the plant tissue and cultivated in parencym and released phytotoxin, such as toxoflavin which cause blight on the grain (Zhou-qi et al., 2016). Bacterial infections may occur through wounds that are affected by environmental conditions, such as temperature, humidity, sunlight, and the availability of water from the host plants (Habazar $\&$ Rivai, 2004). The time of the incubation period depends on 3 main factors, including bacterial pathogens (how to inoculate into plants, concentration, inoculum, and type of diseases), host plants (species, age, and organs), and environment (temperature and humidity) (Habazar \& Rivai, 2004). Li et al. (2016) showed that bacterial infection occurs during high temperature and moisture. Our research showed that disease symptoms on plant was appreared on 8 DAI, which seen on grain, panicle and leaf sheat (Figure1). Severe infected grains changed into blackish brown (Figure 1A) compared to the healthy seed (Figure 1B). The infected panicles also changed into brown color (Figure 1C). Infected but still filled rice seeds will change color to light brown until slightly dark brown in one third to half of the seed coat (Department of Primary Industry, 2012). The leaf sheath became a brownish color and showed rot symptoms (Figure 1D-E). Saichuk (2009) said that symptoms of rice panicle blight disease could be a broad linear wound from the petiole which created from flag leaf downward, reddish brown striped wound and gray and nectrotic on the centre. Control plant (inoculated with sterile aquadest) also showed disease symptoms. This might occur because there was transmission through water or plant media, which the distance among the buckets was $30 \mathrm{~cm}$. The bacterial cell could probably move and enterd via aquadest injection wound on control plants. Possible seed-borne pathogens also caused symptoms appeared on control plants, considering B.glumae is included as seed-borne bacteria and there was no seed treatment before planting.

Disease Severity. Percentage of disease severity on the 13th day after inocultion can be seen in Table 3 . There was no interaction affect between rice variety and tested isolated to disease severity, therefore the data is a rice variety single affect. The highest disease severity was on Inpari 4 variety $(35.08 \%)$ and Cisokan variety $(33.61 \%)$. These two varieties had the disease severity percentage which did not significantly affect significantly, followed by Situbagendit variety and Cidenu variety which did not affect significantly to disease

Table 1. Criteria of plant resistance

\begin{tabular}{lc}
\hline Resistance criteria & Disease incidence $(\%)$ \\
\hline Resistant & 0 \\
Moderate & $20-30$ \\
Susceptible & $50-60$ \\
Highly susceptible & 100 \\
\hline
\end{tabular}


Table 2. Disease incidence of panicle blight disease due to infection of B. glumae bacteria on rice after 8, 10, 11, 12 , and 13 DAI

\begin{tabular}{|c|c|c|c|c|c|c|}
\hline \multirow{2}{*}{ Varieties } & \multicolumn{4}{|c|}{ Isolat } & \multirow[b]{2}{*}{ B5 } & \multirow{2}{*}{ Average } \\
\hline & B1 & B2 & B3 & B4 & & \\
\hline \multicolumn{7}{|c|}{ Disease incidence 8 DAI (\%) } \\
\hline V1 & 0 & 0 & 0 & 0 & 0 & 0 \\
\hline $\mathrm{V} 2$ & 0 & 0 & 0 & 0 & 0 & 0 \\
\hline $\mathrm{V} 3$ & 0 & 0 & 0 & 33.33 & 100 & 6.67 \\
\hline V4 & 0 & 0 & 33.33 & 66.67 & 0 & 40 \\
\hline V5 & 0 & 0 & 0 & 66.67 & 0 & 13.33 \\
\hline Average & 0 & 0 & 6.67 & 33.33 & 20 & \\
\hline \multicolumn{7}{|c|}{ Disease incidence 10 DAI (\%) } \\
\hline V1 & 33.33 & 66.67 & 66.67 & 0 & 0 & 33.33 \\
\hline $\mathrm{V} 2$ & 0 & 66.67 & 66.67 & 33.33 & 0 & 33.33 \\
\hline V3 & 0 & 33.33 & 66.67 & 66.67 & 33.33 & 40.00 \\
\hline V4 & 0 & 0 & 100 & 66.67 & 100 & 53.33 \\
\hline V5 & 0 & 33.33 & 100 & 100 & 33.33 & 53.33 \\
\hline Average & 6.67 & 40.00 & 80.00 & 53.33 & 33.33 & \\
\hline \multicolumn{7}{|c|}{ Disease incidence 11 DAI (\%) } \\
\hline V1 & 33.33 & 100 & 100 & 0 & 0 & 46.67 \\
\hline $\mathrm{V} 2$ & 0 & 66.67 & 100 & 66.67 & 0 & 46.67 \\
\hline V3 & 0 & 66.67 & 66.67 & 100 & 33.33 & 53.33 \\
\hline V4 & 0 & 33.33 & 100 & 66.67 & 100 & 60.00 \\
\hline V5 & 0 & 100 & 100 & 100 & 66.67 & 73.33 \\
\hline Average & 6.67 & 73.33 & 93.33 & 66.67 & 40.00 & \\
\hline \multicolumn{7}{|c|}{ Disease incidence 12 DAI (\%) } \\
\hline V1 & 33.33 & 100 & 100 & 100 & 100 & 86.67 \\
\hline $\mathrm{V} 2$ & 100 & 66.77 & 100 & 66.77 & 100 & 86.67 \\
\hline V3 & 66.77 & 100 & 66.67 & 100 & 100 & 86.67 \\
\hline V4 & 100 & 100 & 100 & 100 & 100 & 100 \\
\hline V5 & 33.33 & 100 & 100 & 100 & 33.33 & 86.67 \\
\hline Average & 66.67 & 93.33 & 93.33 & 93.33 & 100 & \\
\hline \multicolumn{7}{|c|}{ Disease incidence 13 DAI (\%) } \\
\hline V1 & 100 & 100 & 100 & 100 & 100 & 100 \\
\hline $\mathrm{V} 2$ & 100 & 100 & 100 & 100 & 100 & 100 \\
\hline V3 & 100 & 100 & 100 & 100 & 100 & 100 \\
\hline V4 & 100 & 100 & 100 & 100 & 100 & 100 \\
\hline V5 & 100 & 100 & 100 & 100 & 100 & 100 \\
\hline Average & 100 & 100 & 100 & 100 & 100 & \\
\hline
\end{tabular}

DAI: days after inoculation 
severity percentage ( $31.17 \%$ and $26.17 \%$ respectively). The mildest disease severity was found in Inpari 32 varieties with a percentage of $21.37 \%$. Each variety has a different percentage of disease severity because it has different resistant genes. Variations in plant susceptibility to pathogens are caused by differences in the types and numbers of genes for resistance that may be present in each variety (Agrios, 2005). Rice resistant to panicle blight bacteria involves activation of resistance genes (Magbanua et al., 2014). Pink \& Hand (2002) stated that there were grouped resistance gene loci, rice may have used a group of resistance genes to carry out a mechanism of resistance to bacteria that cause panicle blight. In addition, an increase in the population of $B$. glumae bacteria in panicles wrapped in leaf sheaths at the filling stage also affects the severity of the disease (Hikichi, 1993). The disease severity varied and the value was below $50 \%$. This occured because each tested variety has a system of resistance to pathogens. Agrios (2005) said that plants have 2 systems of resistance, namely those that are partial (owned by all plants) and those that are $\mathrm{R}$ genes (the dominance of $\mathrm{R}$ genes for a particular pathogen). A similar plant variety is inoculated with different pathogenic isolates, it is possible that the variety will be susceptible to some of these isolates and will be resistant to several other isolates. This shows that varieties can have one or more resistant genes against each pathogenic isolate.

The highest disease severity was caused by DSM $9512^{\mathrm{T}}$ isolate (30.09\%), followed by IC PRC and IR64 isolates which were not significantly different (37.28\% and $35.80 \%$ respectively), and the lowest disease severity was found in CHBJ isolate and control treatments (aquadest) which were not significantly different, i.e. $22.59 \%$ and $21.65 \%$ respectively.
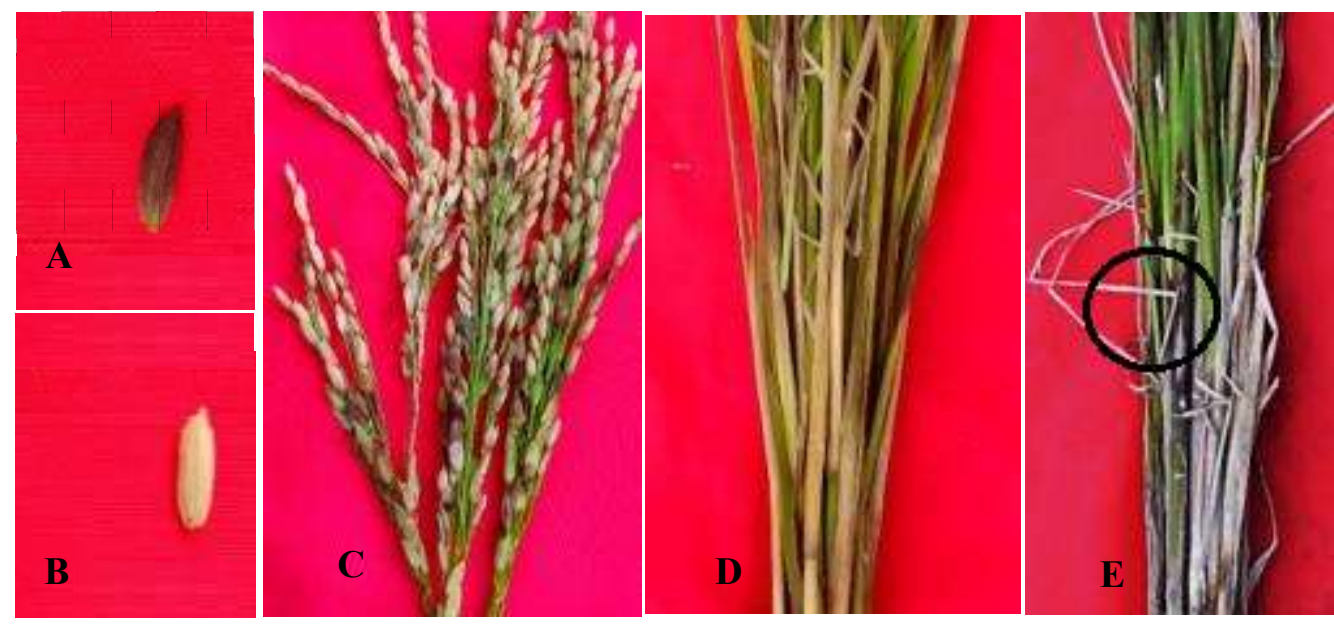

Figure 1. Panicle blight disease; (A) infected rice grain by $B$. glumae and (B) healthy rice grain, (C)symptoms on panicle, (D) symptoms on rice leaf sheat, (E) symptoms around inoculation area (black circle).

Table 3. Disease severity due to infection of B. glumae bacteria on rice 13 DAI

\begin{tabular}{lcccccc}
\hline & \multicolumn{7}{c}{ Disease severity (\%) } \\
\cline { 2 - 6 } Varieties & B1 & B2 & B3 & B4 & B5 & Average \\
\cline { 2 - 6 } & 23.47 & 22.20 & 37.20 & 39.67 & 45.53 & $33.61 \mathrm{~b}$ \\
n1 (Cisokan) & 20.93 & 25.93 & 34.13 & 62.13 & 32.27 & $35.08 \mathrm{~b}$ \\
V2 (Inpari 4) & 25.47 & 19.67 & 43.80 & 42.93 & 24.00 & $31.17 \mathrm{ab}$ \\
V3 (Situbagendit) & 20.40 & 24.27 & 25.20 & 17.40 & 19.60 & $21.37 \mathrm{a}$ \\
V4 (Inpari 32) & 18.00 & 20.87 & 38.67 & 24.27 & 29.07 & $26.17 \mathrm{ab}$ \\
\hline V5 (Cidenu) & $21.65 \mathrm{a}$ & $22.59 \mathrm{a}$ & $35.80 \mathrm{~b}$ & $37.28 \mathrm{~b}$ & $30.09 \mathrm{ab}$ \\
\hline Average & & & & &
\end{tabular}

DAI: days after inoculation 
The Effect of Varieties and Isolates on the Number of Grains, Empty Grains and Weight of 100 Grains. The results of data analysis showed that there was no interaction effect between rice varieties and isolates tested to the number of grains and weight of 100 grains, but they were affected the percentage of empty grains, thus the data displayed were independent effects of isolate factors. The tested rice varieties showed different affects to the average number of grains (Table 4). The highest average number of grain was found in the Cisokan variety (2,240.34 grains), followed by Inpari $4(2,229.87)$ and Situbagendit $(2,131.87)$, Cidenu $(2,082.80)$, and Inpari 32(1,955.87) (Table 4). The number of grain is influenced by genetic factors, abiotic and biotic conditions. The grain yield is also strongly influenced by the suitability of the varieties planted, the presence and severity of pests' and diseases' attacks and environmental conditions (water availability, appropriate fertilization), agroecological factors, and genetic factors (panicle and panicle branches) (Wibowo, 2010; Sitinjak \& Idwar, 2015). Several different $B$. glumae isolates from North Sumatra caused significant differences in the average number of grains of several rice varieties (Weny, 2018, Weny et al., 2019).

Bacterial isolates had a very significant effect on the number of grains (Table 3 ). The average number of the highest to the lowest grain were found in the control treatment $(2,379.27$ grains), IR 64 isolate $(2,153.07$ grains), IC PRC isolate (2,058.27 grains), and DSM $9512^{\mathrm{T}}$ isolates $(2,080.07$ grains $)$. The average number of grain did not differ significantly from the IC PRC and DSM $9512^{\mathrm{T}}$ isolate. The lowest number of grains was found in plants inoculated with CHBJ isolates (1,970.07 grains).

The highest percentage of empty grains were Inpari 4 varieties $(32.72 \%)$, Cidenu $(28.68 \%)$ and Situbagendit (24.90\%), Cisokan (24.90\%) respectively. While the lowest percentage of empty grains was Inpari

Table 4. Average number of grains (grain), empty grain (\%), weight of 100 grains (g)

\begin{tabular}{|c|c|c|c|c|c|c|}
\hline \multirow{2}{*}{ Varieties } & \multicolumn{5}{|c|}{ Isolates } & \multirow{2}{*}{ Average } \\
\hline & $\mathrm{B} 1$ & B2 & B3 & B4 & B5 & \\
\hline \multicolumn{7}{|c|}{ Number of grains (grain) } \\
\hline V1 & 2465 & 2244.67 & 2165.67 & 2188.67 & 2137.67 & $2240.34 c$ \\
\hline $\mathrm{V} 2$ & 2559.67 & 1970 & 2274.33 & 2050.67 & 2294.67 & $2229.87 b c$ \\
\hline V2 & 2414.33 & 1783.33 & 2145 & 2127 & 2189.67 & $2131.87 b c$ \\
\hline V4 & 2134.33 & 1777.67 & 2080.67 & 1770.67 & 2015 & $1955.87 \mathrm{a}$ \\
\hline V5 & 2323 & 2074.67 & 2098.67 & 2154.33 & 1763.33 & $2082.80 \mathrm{ab}$ \\
\hline Average & $2379.27 \mathrm{c}$ & $1970.07 \mathrm{a}$ & $2153.07 b$ & $2058.27 \mathrm{ab}$ & $2080.07 \mathrm{ab}$ & \\
\hline \multicolumn{7}{|c|}{ Percentage of empty grains $(\%)$} \\
\hline V1 & $11.81 \mathrm{a}$ & 17.65abcdefghij & 24.88efghijklmn & 29.93klmnopqr & 26.06ghijklmno & 22.07 \\
\hline $\mathrm{V} 2$ & $12.59 \mathrm{abc}$ & 26.25ghijklmnop & 30.07klmnopqrs & $50.68 \mathrm{v}$ & $44.01 \mathrm{uv}$ & 32,72 \\
\hline V3 & $12.70 \mathrm{abcd}$ & $44.54 \mathrm{uv}$ & 28.30hijklmnopq & 22.80cdefghijkl & 16.17abcdefgh & 24.90 \\
\hline V4 & 13.82abcdef & $12.65 \mathrm{abcde}$ & 14.13abcdefg & 24.46cdefghijklm & 16.90abcdefghi & 16.59 \\
\hline V5 & $11.93 \mathrm{ab}$ & 35.90mnopqrstu & 20.98abcdefghijk & 43.31tuv & 31.26klmnopqrst & 28.68 \\
\hline Average & 12.57 & 27.60 & 23.67 & 34.24 & 26.88 & \\
\hline \multicolumn{7}{|c|}{ Weight of empty grains (g) } \\
\hline V1 & 2.30 & 2.51 & 2.27 & 2.24 & 2.38 & $2.34 \mathrm{a}$ \\
\hline $\mathrm{V} 2$ & 2.51 & 2.58 & 2.48 & 2.51 & 2.42 & $2.50 \mathrm{ab}$ \\
\hline V3 & 2.70 & 2.59 & 2.30 & 2.74 & 2.47 & $2.56 \mathrm{bc}$ \\
\hline V4 & 2.74 & 2.79 & 2.83 & 2.63 & 2.66 & $2.73 c$ \\
\hline V5 & 2.61 & 2.82 & 2.72 & 2.68 & 2.70 & $2.71 \mathrm{c}$ \\
\hline Average & $2.57 \mathrm{~A}$ & $2.66 \mathrm{~A}$ & $2.52 \mathrm{~A}$ & $2.56 \mathrm{~A}$ & $2.53 \mathrm{~A}$ & \\
\hline
\end{tabular}

V1 (Cisokan), V2 (Inpari 4), V3 (Situbagendit), V4 (Inpari 32), V5 (Cidenu), B1 (akuades), B2 (CHBJ), B3 (IR64), B4 (IC PRC), B5 (DSM 9512 $)$. Numbers that are followed by the same columns and rows do not differ based on Tukey HSD test with significant level 5\%. 
32 varieties (16.59\%). The interaction between varieties and bacterial isolates also had a very significant effect on the percentage of empty grains (Table 4). The highest percentage of empty grain was found in $\mathrm{V}_{2} \mathrm{~B}_{4}$ treatment (interaction between Inpari 4 and IC PRC isolate), i.e. $50.68 \%$. The high percentage of empty grain can be caused by the susceptibilty of rice varieties to bacteria. Actually chemical plant defense mechanisms such as phytoalexin are also found in susceptible varieties, but these compounds are produced after infection with pathogens spreads in plant tissues, therefore they are unable to inhibit pathogen development (Habazar \& Rivai, 2004).

Data of weigth of 100 grains can be seen in Table 4. Similar to the number of grains, weight of 100 grains was also only affected by varieties. The highest average weight of 100 grains of rice was found in Inpari $32(2.73$ g) and Cidenu $(2.71 \mathrm{~g})$ which were not significantly different, followed by Situbagendit (2.56 g) and Inpari $4(2.50 \mathrm{~g})$. The lowest average weight of 100 grains of rice was found in the Cisokan variety $(2.34 \mathrm{~g})$.

Plant Resistance. The percentage of disease incidence reached $100 \%$ at 13 DAI and showed visual symptoms that appeared in all varieties, in the form of brown spots that extend on the leaf sheath, grayish color in the inoculation area and brown spots to black on the grains and became empty.

The results showed that the disease incidence of $100 \%$ in the five tested rice varieties (Cisokan, Inpari 4, Situbagendit, Inpari 32, and Cidenu varieties), therefore the resistance criteria were categorized as very susceptible to bacterial panicle blight on the basis of Groth et al. (1991) criteria.

\section{CONCLUSION}

Cisokan, Inpari 4, Situbagendit, Inpari 32, and Cidenu varieties were very susceptible to bacterial panicle blight. There was no effect of interaction between varieties and isolates on the disease incidence and disease severity, as well as the number of grains and the weight of 100 grain grains, but they only affected the percentage of empty grains.

\section{ACKNOWLEDGMENTS}

The authors would like to thank to Universitas Sumatera Utara through Program of TALENTA grant 2018 (No. 339/UN5.2.3.1/PPM/KP-TALENTA USU/2018) for financially support this research.

\section{REFERENCES}

Agrios GN. 2005. Plant Pathology New Fifth Edition. Elsevier Academic Press, New York.

Baharuddin, Harniati R, Faisal, F, Yani A, Suparmi, Hamid H, Kuswinanti T, \& Jahuddin R. 2017. Keberadaan penyakit busuk bulir (Burkholderia glumae) pada tanaman padi di Sulawesi Selatan. In: Pradana MG \& Mubin N (Eds.). Prosiding Simposium Nasional Fitopatologi Indonesia 2017. pp. 12. Bogor, Indonesia. January 10, 2017.

Department of Primary Industries. 2012. Exotic Pest Alert: Bacterial Panicle Blight. Primefact 1215, Second edition. Plant Biosecurity \& Product Integrity. Australia.

Devescovi G, Bigirimana J, Degrassi G, Cabrio L, LiPuma JJ, Kim J, Hwang I, \& Venturi V. 2007. Involvement of a quorum-sensing-regulated lipase secreted by a clinical isolate of Burkholderia glumae in severe disease symptoms in rice. Appl. Environ. Microb. 73(15): 4950-4958.

Groth DE, Rush MC, \& Hollier CA. 1991. Rice Diseases and Disorders in Louisiana. Louisiana State University Agricultural Center, Baton Rouge, Louisiana.

Habazar T \& Rivai F. 2004. Bakteri Patogenik Tumbuhan. Andalas University Press, Padang.

Hasibuan M, Safni I, Lisnawita, \& Lubis K. 2017. Morphological characterization of several strains of the rice pathogenic bacterium Burkholderia glumae in North Sumatra. IOP Conf. Series: Earth and Environmental Science. 122: 012044.

Hikichi Y. 1993. Relationship between population dynamics of Pseudomonas glumae on rice plants and disease severity of bacterial grain rot of rice. J. Pest Sci. 18(4): 319-324.

Joko T. 2017. Burkholderia glumae sebagai Emerging Pathogen: Status, Potensi Kerusakan, dan Strategi Pengendalian. In: Pradana MG \& Mubin N (Eds.). Prosiding Simposium Nasional Fitopatologi. pp. 27-35. Bogor, Indonesia. January 10, 2017.

Kumar S, Meshram S, \& Sinha A. 2017. Bacterial diseases in rice and their eco-friendly management. Inter. J. Agric. Sci. Res. 7(2): 3142. 
Li L, Wang L, Liu LM, Hou YX, Li QQ, \& Huang SW. 2016. Infection process of Burkholderia glumae before booting stage of rice. J. Phytopathol. 164(10): 825-832.

Magbanua ZV, Arick M, Buza T, Hsu CY, Showmaker KC, Chouvarine P, Deng P, Peterson DG, \& Lu S. 2014. Transcriptomic dissection of the rice Burkholderia glumae interaction. BMC Genomics. 15: 755.

Nandakumar R, Shahjahan AKM, Yuan XL, Dickstein ER, Groth DE, Clark CA, Cartwright RD, \& Rush MC. 2009. Burkholderia glumae and B. gladioli cause bacterial panicle blight in rice in the Southern United States. Plant Dis. 93(9): 896-905.

Pink DAC \& Hand P. 2002. Plant resistance and strategies for breeding resistant varieties. Plant Protection Science. 38(Special issue 1): 9-13.

Razie F, Anas I, Sutandi A, Sugiyanta, \& Gunarto L. 2013. Efisiensi serapan hara dan hasil padi pada budidaya SRI di persawahan pasang surut dengan menggunakan kompos diperkaya. J. Agron. Indonesia. 41(2): 89-97.

Saichuk J. 2009. Louisiana Rice Production Handbook. Baton Rouge, LA, USA: LSU Agricultural Center.

Sitinjak H \& Idwar. 2015. Respon berbagai varietas padi sawah (Oryza sativa L.) yang ditanam dengan pendekatan teknik budidaya Jajar Legowo dan Sistem Tegel. JOM Faperta. 2(2): 1-15.

Suryani L. 2017. Burkholderia glumae Penyebab Hawar pada Malai Padi. Balai Karantina Pertanian Kelas 1, Banjarmasin.

Trung HM, Van NV, Vien NV, Lam DT, \& Lien M. 1993. Occurrence of Rice Grain Rot Disease in Vietnam. Int. Rice Res. Notes. 18(3): 30.
Wamishe Y, Kelsey C, Belmar S, Gebremariam T, \& McCarty D. 2015. Bacterial Panicle Blight of Rice in Arkansas. University of Arkansas, United States.

Weny. 2018. Uji Ketahanan Lima Varietas Padi (Oryza sativa L.) terhadap Penyakit Hawar Malai Bakteri (Burkholderia glumae) di Rumah Kaca. Skripsi. Universitas Sumatera Utara, Medan.

Weny, Safni I, Lisnawita, \& Lubis K. 2019. Screening for disease resistance in rice varieties against bacterial panicle blight disease (Burkholderia glumae) in Northern Sumatra of Indonesia. IOP Conf. Series: Earth and Enviromental Science 260: 012118.

Wibowo P. 2010. Pertumbuhan dan Produktivitas Galur Harapan Padi (Oryza sativa L.) Hibrida di Desa Ketaon Kecamatan Banyudono Boyolali. Skripsi. Universitas Sebelas Maret, Surakarta.

Wiyono S, Giyanto, Mutaqin KH, Hidayat SH, Supramana, \& Widodo. 2017. Emerging Diseases pada Tanaman Pertanian: strategi dan opsi kebijakan pengendalian. In: Pradana MG \& Mubin N (Eds.). pp. 1. Simposium Nasional Fitopatologi 2017. Bogor. January 10, 2017.

Xie GL, Luo JY, \& Li B. 2003. Bacterial panicle blight: a rice dangerous diseases and its identification. Plant Prot. 29: 47- 49.

Zhou-qi C, Bo Z, Guanlin X, Bin L, \& Shiwen H. 2016. Research status and prospect of Burkholderia glumae, the pathogen causing bacterial panicle blight. Rice Sci. 23(3): 111-118. 